\title{
Transformation of Research Instrument Development in Education
}

\author{
Mohd Sahandri Gani Bin Hamzah, Noor Shah Saad \\ Sultan Idris Education University, Tanjong Malim, Malaysia \\ Saifuddin Kumar Abdullah \\ Ministry of Education, Putrajaya, Malaysia \\ Mazura Mastura Muhammad \\ Sultan Idris Education University, Tanjong Malim, Malaysia \\ Husni Zaim Khairun Nasri \\ University Malaysia Terengganu, Kuala Terengganu, Malaysia
}

\begin{abstract}
The usage of education and social science research instruments is the most important component in determining research design because it involves the process of data collection and the retrieval of correct information to be reported as a process in the results of a study. Since the measurement scales used consist of many forms, such as the Thurstone technique, the Likert scale, semantic difference, and categorical scales, in which "Yes" (1) or "No" (0) is labeled with numbers ordered according to priority. Through earlier analyses, the accuracy of the usage of these scales can be argued because each of the scores does not have clear and concrete proofs. Because of that, an instrument creation approach based on the form of rubric score is interpreted to a 5-point ordinal scale. For example, the process of constructing an instrument for a study titled "Creativity Aided Pedagogy" requires discreet literature readings to determine the constructs, sub-constructs, and variables, which possess descriptors in the rubric form. An instrument determining table is developed to summarise the related elements until an item that can measure a construct or sub-construct is produced. After the validation process is conducted and a pilot study is executed, the item analysis to determine the status of the statement can be explained by the score of every rubric objectively and systematically. For example, for the construct of a teaching aid, the mean score recorded was 3.2, which is at the average level (standard criteria). However, whiteboards are used frequently compared with other forms of teaching aids, such as charts and manila cards. For the effect of using electronic teaching aids in the centralisation process, the mean score recorded was 3.8, which is good or high. However, there are also shown weaknesses, where the teacher is not using liquid crystal display (LCD) (16.4\%). The dominant factor that encouraging the teacher is to use compact disc (CD) (63.0\%) as a creative aided pedagogy. Furthermore, the effect of using a creative aided pedagogy is high (minimum score 4.1) and it has a significant effect on the teaching and learning processes, but teachers need to spend more time on teaching preparation. It is hoped that the process of transforming the
\end{abstract}

Mohd Sahandri Gani Bin Hamzah, B.S., Ed.M., Ed.D., professor, Faculty of Education and Human Development, Sultan Idris Education University.

Noor Shah Saad, B.S., Ed.M., Ed.D., professor, Faculty of Education and Human Development, Sultan Idris Education University.

Saifuddin Kumar Abdullah, B.A., M.A., Ed.D. candidate, Department of Polytechnic, Ministry of Education.

Mazura Mastura Muhammad, Ph.D., Faculty of Languages and Communication, Sultan Idris Education University.

Husni Zaim Khairun Nasri, B.ASc., Faculty of Science of Technology, University Malaysia Terengganu. 
development of new era instruments can be increasingly effective in measuring what should be measured in the study of education and social science.

Keywords: transformation, instruments, construction, education

\section{Introduction}

In a large-scale research, most activities are conducted using study instruments measured on the ordinal scale. The usage of such instruments facilitates data collection processing. Besides that, the items available in the instruments were chosen and adapted based on situations which closely relate to the research variables and titles. In a brief survey, only $12.5 \%$ of researchers are able to contruct their own research instruments.

Currently, there is a trend in research which uses the Likert scale, either the 4-point, 5-point, 6-point, or the 9- or 10- point score called semantic differential instruments that yield different interpretations. Generally, it ranges from the interpretation of "Strongly disagree" to "Strongly agree" in two different extremes.

However, based on this study, the researchers have implemented transformations on the development of research intruments using the dual-layer rubric scale. This approach is able to provide a detailed input not only in terms of the status of the score scale, but also the ability in explaining according to the rubric score level. The strength of this instrument for every item or statement not only focuses on the mean score status, but it also further specifies towards the weaker, moderate, or stronger level with clearer descriptive elaborations. The findings would also be read more easily in reports, solutions would easily be found, and more accurate and meaningful suggestions can be recorded.

\section{Field of Evaluation}

The developed instrument focuses on creative teaching materials. Two main constructs were identified through the theory of teaching and learning and literatures. For this, three sub-constructs for each main construct were determined, followed by the variables that can measure the said sub-constructs.

Each statement represented by the item is rubricated with significant and relevant rubrics to be measured. The item scales are determined using the 5-level scale, while five rubrics for every item are shown with the score of 0 for non-related evidents, 1 for indirect involvement within respondents, and 2 for full involvement.

The respondents only have to give evaluations related to the rubric score whereas the statements are completed by the researchers. This constructive principle will neutralise biase towards the determination of scales.

\section{Problem Statement}

Good instruments answer research questions accurately. Because of that, all problems can be solved with all report adaptations as well as being reader-friendly and easily understood. One of the important components of designing a research is the instrumentation of research where it has the potential to collect all data and information accurately. Based on the analysis on previeous research, $87.5 \%$ of researchers used ready-made instruments which were then adapted in the modification of few constructs and variables to suit the instrument to the study focus. Hence, there are constructs and variables which are less accurate, and the methods using 
evaluation scales are based on the perception of the respondents.

Overall, when a detailed analysis is conducted on the item responses, it was found that the majority of respondents chose the scales 4 and 5 compared with scales 1,2, and 3. This problem exists because the items are only based on estimated perceptions without sound proofs, like rubrics. Besides that, the number facts are only summarised in the form of numericals which are unable to explain the strengths shown in the rubric items for each variable.

Besides that, a bigger problem surfaced as many instruments used did not come from literatures that can lead to the origins of variables in constructs that allow evaluation on an item. Also, the mean score for each item is different based on the cohorts of the respondents, where no standard criterion exists in determining the mean score for each instrument. Another problem arised is the item validation process that was not done on the validity content that should be conducted by evaluative professionals and also using the Instrument Determination Table.

An instrument that possesses more than 10 items in a construct does not comply with item developing principles. Because of that, the researchers of this paper feel responsible to share the experience of solving the basic problems in research especially in developing instruments.

\section{Objectives}

The objectives of this study are:

1. To develop a dual-layer rubric instrument;

2. To integrate data using qualitative and quantitative statistics;

3. To write a report reated to more detailed and meaningful findings.

\section{Research Questions}

This study was guided by the following three research questions:

1. How is the instrument transformation process developed?

2. How is the item analysis conducted qualitatively and quantitatively?

3. What is the extent of reporting findings using a more detailed and meaningful explanation?

\section{Instrument Literatures}

\section{Teaching Materials}

Teaching aids. Through various teaching aids, interactive learning will attract interest and attention while invoking deep inquisitivity within students. The rationale of using teaching aids in the teaching and learning processes is to clarify information presentation so that it is not too verbalistic, overcomes spatial limitations, and conquers the passive nature of students while providing stimulation, relating experiences, as well as raising perceptions within students (Zainudin, Tengku, Mohad, \& Hamdan, 2007).

Software. The usage of multimedia software changes presenting conventional teaching methods into newer models of student-based teaching and learning. For example, one of the suitable methods to teach students mathematics and science in English is using the multimedia software (Hussein, 2006). According to Vijaya and Nair (1996), multimedia is the integration of sound, audio, static graphic, animation, and video projection technologies. Multimedia is even able to create an effective and enjoyable learning situation because students remember $20 \%$ of what they see, $30 \%$ of what they see and hear, and $60 \%-70 \%$ of what they interact. 
Equipment/tools. In the teaching process, a person uses a variety of perceptions. The more senses used, the more effective learning becomes. This is because senses complement deficiencies and strengthen the perception of other senses. Hence, the equipment that requires usage of a variety of senses will ultimately be more effective. Tools that come in attractive colours and shapes will draw more attention. This is also true for tools that can be seen, heard, and felt (Atan, 1978).

\section{Learning Materials}

Textbooks. One of the factors that contributes towards the effectiveness of teaching and learning is textbooks. Quality textbooks are welcomed by students if the contents are suitable for their age, backgrounds, and needs. Good textbooks should also be arranged based on studies that involve the context and culture languages. Furthermore, textbooks are able to increase the interests and the tentencies of students to follow the offered courses as well as to appreciate the expansion of knowledge discussed (Husaini \& Khairul, 2008).

Based on Circular Letter No. 1/2000 of the Ministry of Education (2000), the usage of workbooks has raised many reactions from teachers and parents. In this matter, the ministry is of the opinion that a good and content-suitable workbook can be used to enrich teaching and learning in the classroom without disregarding textbooks. It is, however, stressed that textbooks are the main compulsory materials to be used in the teaching and learning processes while workbooks only act as extra materials.

Teaching/learning aids. The importance of technology in the current context of a knowledgeable society has been increasing. This rapid expansion could help in increasing technology usage towards glorifying the educational system in Malaysia. This situation seeks the need of quality in increasing effective supporting infrastructures in teaching and learning through the usage of teaching aids that can open a wider space for teachers to apply all theories, skills, and expertise available (Siti Fatimah \& Ab. Halim, 2010). This matter is also supported by Kamarul and Ab. Halim (2007) that educational technology-based teaching aids can be practiced to increase the effectiveness of teaching and learning besides attracting interests and attention of students through a properly planned usage.

\section{Conceptual Framework}

The overall process of developing a research instrument involves three components beginning with input, where all related materials and syllabi are separated based on the findings from literatures and previous studies. A follow-up action is then conducted based on systematic contruction processes according to standard operating procedures. The detailing process begins with planning to develop an Intrument Determining Schedule (IDS) model (see Figure 1). Figure 1 shows the conceptual framework that involves the process of constructing an instrument set using the correct principles and procedures.

The metrics of the IDS (see Table 1) consist of the process of planning and determining the complete taking rubric scores and scales into account. The determined constructs and sub-constructs were supported by the literatures whereas the designs of traits and items related to the subjects and predicates are controlled by the syllabus and the principle of measuring and assessing. The purification process on every item and variable is supported by experts in the measurements related to the study. At the end of the procedure, a set of instruments was successfully produced. All the steps that cut across components were supervised by the researchers through the Action Theory originated from Parson (1978). 


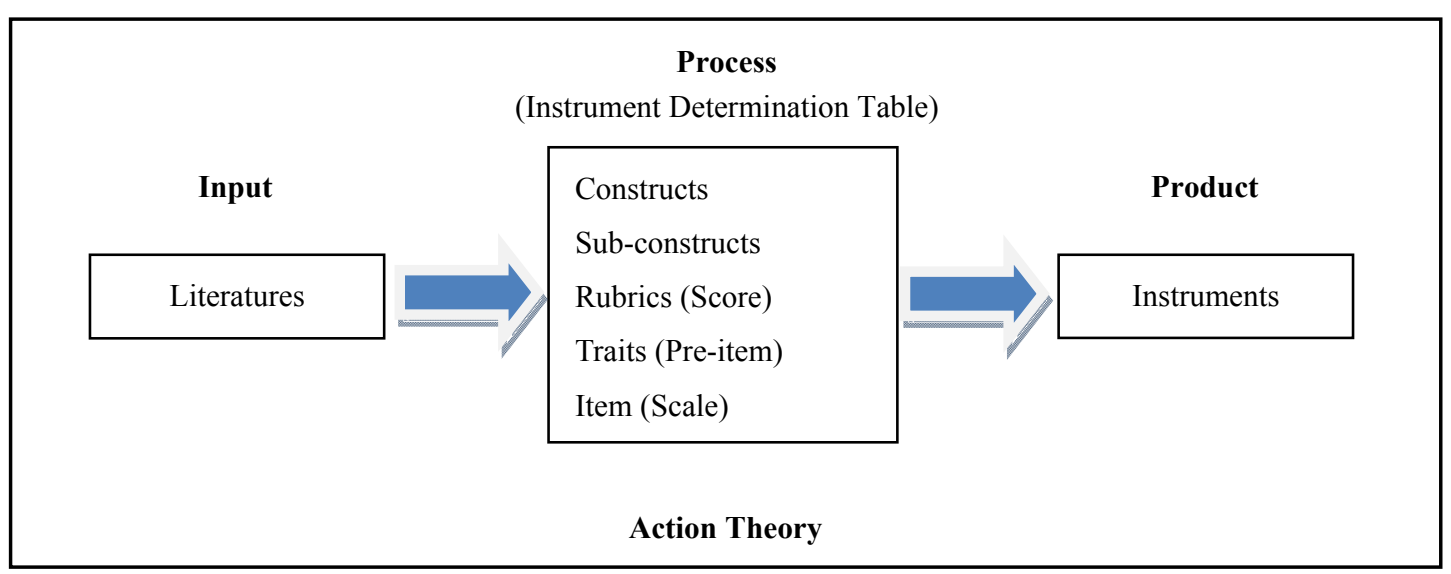

Figure 1. Instrument conceptual framework.

Table 1

IDS

\begin{tabular}{|c|c|c|c|c|c|}
\hline Construct & Variable & Question & Rubric & Item & Scale \\
\hline \multirow{4}{*}{ Teaching aids } & $\begin{array}{l}\text { 1. Non-electronic } \\
\text { teaching aids }\end{array}$ & $\begin{array}{l}\text { 1. What is the type and } \\
\text { frequency of using } \\
\text { non-electronic teaching } \\
\text { aids? }\end{array}$ & $\begin{array}{l}\text { Blackboard, charts, manila } \\
\text { cards, figures, and magnetic } \\
\text { boards } \\
\text { Rubric score: } \\
0 \text { (none), } 1 \text { (1-2 times), and } 2 \\
\text { (3 times or more) } \\
\end{array}$ & $\begin{array}{l}\text { Table } 2 \\
\text { (Item 1) }\end{array}$ & Ordinal scales 1-5 \\
\hline & $\begin{array}{l}2 . \quad \text { Electronic } \\
\text { teaching aids }\end{array}$ & $\begin{array}{l}\text { 2. What is the type and } \\
\text { frequency of using } \\
\text { electronic teaching aids? }\end{array}$ & $\begin{array}{l}\text { Overhead projector (OHP), } \\
\text { liquid crystal display (LCD) } \\
\text { projector, computer, television, } \\
\text { and compact disc (CD) players } \\
\text { Rubric score: } \\
0 \text { (none), } 1 \text { (1-2 times), and } 2 \\
\text { (3 times or more) }\end{array}$ & $\begin{array}{l}\text { Table 2 } \\
(\text { Item 2) }\end{array}$ & $\begin{array}{l}\text { Rubric } \quad \text { scores: } 0 \\
\text { (none), } 1 \text { (1-2 times), } \\
\text { and 2 } \\
\text { more) }\end{array}$ \\
\hline & \multirow[t]{2}{*}{$\mid \begin{array}{lr}3 . & \text { The effect of } \\
\text { using non-electronic } \\
\text { and } & \text { electronic } \\
\text { teaching aids }\end{array}$} & \multirow[t]{2}{*}{$\begin{array}{l}\text { 3. What are the effects of } \\
\text { using non-electronic and } \\
\text { electronic teaching aids? }\end{array}$} & $\begin{array}{l}\text { Enjoyable, fast, interesting, } \\
\text { easy, and time-saving } \\
\text { Rubric score: }\end{array}$ & \multirow[t]{2}{*}{$\begin{array}{l}\text { Table } 2 \\
\text { (Item 3) }\end{array}$} & \multirow[t]{2}{*}{$\begin{array}{l}\text { Rubric scales: } 0 \text { (No) } \\
\text { and } 1 \text { (Yes) }\end{array}$} \\
\hline & & & 0 (No) and 1 (Yes) & & \\
\hline
\end{tabular}

Based on Table 1, the trial items in the instrument are shown in Table 2.

Table 2

Dual-Layer Item Rubric Score

\begin{tabular}{|c|c|c|c|c|c|c|c|}
\hline \multirow{3}{*}{\multicolumn{5}{|c|}{$\begin{array}{l}\text { Item 1: } \\
\text { My frequency of using non-electronic teaching aids, such as } \\
\text { learning. }\end{array}$}} & \multicolumn{3}{|c|}{ Rubric score } \\
\hline & & & & & 0 & 1 & 2 \\
\hline & & & & & None & $1-2$ times & 3 times or more \\
\hline \multirow{5}{*}{$\begin{array}{c}\text { Low } \\
1 \\
1\end{array}$} & & & & \multirow[t]{5}{*}{ High } & \multicolumn{2}{|c|}{ Blackboard/whiteboards } & \\
\hline & 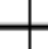 & 1 & a & & \multicolumn{2}{|l|}{ Charts } & \\
\hline & 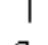 & 1 & & & \multicolumn{2}{|c|}{ Manila cards } & \\
\hline & 2 & 3 & 4 & & \multicolumn{2}{|c|}{ Figures } & \\
\hline & \multicolumn{3}{|c|}{ Ordinal scale (Likert) } & & \multicolumn{2}{|c|}{ Magnetic boards } & \\
\hline
\end{tabular}


(Table 2 to be continued)

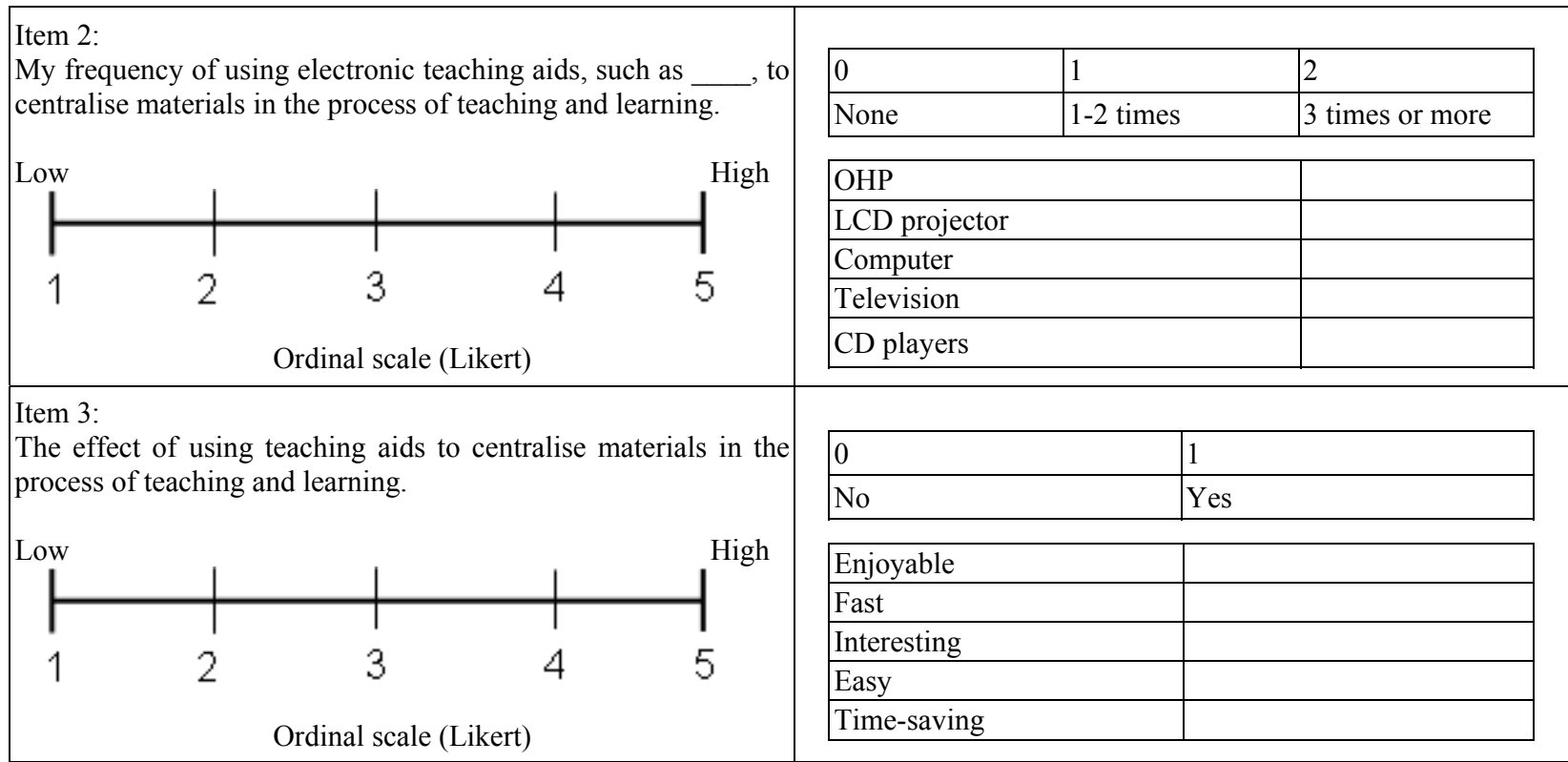

Pilot Study and Findings

The researchers conducted a pilot study to determine the reliability of instruments, recording indices of not less than 0.67 (Nunnally, 1982) for newly constructed intruments. This was also done to maintain the accuracy of the instrument. This pilot study was conducted on 63 master and Doctor of Philosophy (Ph.D.) students. The instrument of this study was piloted using the interaction survey method where students were gathered in two groups and the researchers read and explained each item to obtain the similar understanding within the respondents. However, the response for each item was not guided by the researchers of this paper. Generally, every item was created through the IDS based on the literature, it is not advisable to use factor analysis.

\section{Instrument Validation}

Every item on the instrument was validated by five experts to determine whether or not the item is suitable with the evaluated construct. One of the principles used in validating the intruments is by referring each item that needs to be agreed upon by five content experts. The minimum percentage of agreement for each validated item is not less than $80 \%$.

\section{Reliability}

Data analysis was conducted using the Statistic Package for Social Science (SPSS) Version 19 programme. The steps used are shown in Figure 2.

The reliability result from the processed items based on Figure 2 is shown in Table 3.

Based on Table 3, the coefficient of the item correlation and the total score of non-electronic teaching aids is 0.31 and Cronbach's alpha value if the item was omitted was 0.79 . For electronic teaching aids and teaching aids usage, the item correlation and total score value are 0.49 and 0.54 respectively. Cronbach's alpha values if both items were omitted are 0.78 and 0.76 respectively. However, the item for non-electronic teaching aids did not comply with the rules with 0.31 as the item correlation and total score coefficient. Hence, the item had to be modified and piloted again. The new index for the item correlation and total score coefficient was 0.52 . The overall Cronbach's alpha value standardised for all three items was 0.80 . 


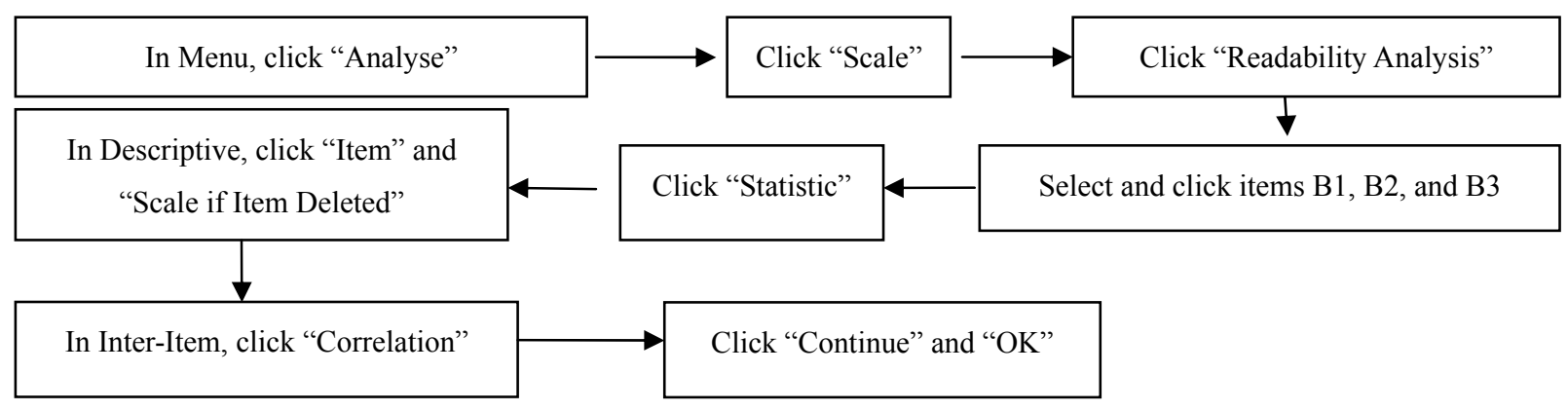

Figure 2. SPSS analysis operation.

Table 3

Item Analysis Summary

\begin{tabular}{llcc}
\hline Item & $\begin{array}{l}\text { Item correlation } \\
\text { score coefficient }\end{array}$ & $\begin{array}{c}\text { and } \\
\text { item is omitted }\end{array}$ & value if Standardised alpha of items \\
\hline Non-electronic teaching aids & $0.52(0.31)^{*}$ & 0.79 & \multirow{2}{*}{0.80} \\
Electronic teaching aids & 0.49 & 0.78 & \\
The effects of using teaching aids & 0.54 & 0.76 & \\
\hline
\end{tabular}

Note. ${ }^{*}$ Correlation coefficient value before being modified.

\section{Instrument Data Analysis}

According to Anita and Jamil (2012), researchers may sometimes use many theories and their own formulas to create their own index based on the need of the study. Because of that, the researchers have introduced an interpretation to classify mean values as high, moderate, or low. All three categories are shown in Table 4.

Table 4

Three Categories of Score Mean Interpretation

\begin{tabular}{lll}
\hline Low level & Moderate level & High level \\
\hline $1.00-2.33$ & $2.34-3.66$ & $3.67-5.00$ \\
\hline
\end{tabular}

Note. Referring to Sahandri, Ramlee, Alias, and Rose (2013).

The 5-point Likert scale was used in the research instrument and the researchers of this paper determined three levels to interpret the mean scores. The following formula was used to determine the three levels of interpretations:

$$
\begin{aligned}
& =(5-1) / 3 \\
& =4 / 3 \\
& =1.33
\end{aligned}
$$

where $5=$ The highest score in the 5 -point Likert scale; $1=$ The lowest score in the 5 -point likert scale; $3=$ The determined level; and $1.33=$ The range for each class.

Referring to the formula above, the interpretation of mean score is stated in Table 4.

Based on the SPSS analysis in the descriptive part using the steps and procedures that have started with the click on the analysis icon, and then selected the descriptive statistic and items involved, the results are shown in Table 5.

Based on Table 5, the numbers show mean scores and standard deviation values for the non-electronic 
teaching aids $(M=3.2 ; S D=0.45)$, electronic teaching aids $(M=3.8 ; S D=0.62)$, and the usage of teaching aids $(M=4.1 ; S D=0.50)$ by 63 processed respondents. It shows that the level of using electronic teaching materials is high compared with the non-electronic teaching materials, which is at the moderate level. The respondents also admitted that teaching aids help provide good effects to the users. This interpretation is referred to the standard critera shown in Table 5.

Table 5

Item Mean Score and Classification Status

\begin{tabular}{lllll}
\hline & $N$ & $M$ & $S D$ & Status \\
\hline Non-electronic teaching aids & 63 & 3.2 & 0.45 & Moderate \\
Electronic teaching aids & 63 & 3.8 & 0.62 & High \\
Effects of using teaching aids & 63 & 4.1 & 0.50 & High \\
Valid $N$ (listwise) & 63 & - & - & - \\
\hline
\end{tabular}

\section{Item Descriptives}

The analysis on item descriptives based on the used rubrics is summarised based on the mean scores, weaknesses, and strengths, as shown in Table 6.

Table 6

Item Descriptives

\begin{tabular}{|l|l|l|l|}
\hline Sub-constructs/variables & Mean score & \multicolumn{2}{|c|}{ Remarks } \\
\hline \multirow{2}{*}{ Non-electronic teaching aids } & 3.2 & 1 & The black/whiteboard recorded the highest frequency (82.1\%). \\
\cline { 2 - 4 } & Moderate & 2 & The magnetic board is not used a lot by teachers (76.1\%). \\
\hline \multirow{2}{*}{ Electronic teaching aids } & 3.8 & 1 & There are still teachers who do not use the LCD projector (16.4\%). \\
\cline { 2 - 4 } & High & 2 & CD received the most support (63.0\%). \\
\hline \multirow{2}{*}{ Effects of using teaching aids } & 4.1 & 1 & Learning is fast and enjoyable (between 71.0\%-93.5\%). \\
\cline { 2 - 4 } & High & 2 & It does not save time because of long PowerPoint presentation slides (54.8\%). \\
\hline
\end{tabular}

Table 6 shows descriptive scores in the usage of non-electronic teaching aids that recorded as 3.2, which is at the moderate level. For electronic teaching aids, 3.8 was recorded, which is at the high level.

Even though this item uses the non-electronic teaching aids in the calculation centralised on students at the moderate level, there are strengths where respondents practised writing on whiteboards a lot (82.1\%). However, the significant weakness shown was that the magnetic boards $(76.1 \%)$ were not used as much in classroom instruction.

For the practice of using electronic teaching aids, it was found that the respondents had it at the high level. However, part of the respondents (16.4\%) did not use LCD projectors in classroom instruction. The dominant factor, however, belongs to the usage of $\mathrm{CD}$ players in instruction (63.0\%).

The effects of using teaching aids within the respondents are high. The quality in the usage of teaching aids was explained by the respondents as fun and fast in its mastery. However, the respondents commented that it does not save time because of long PowerPoint presentation slides, which were not simplified and thus became time-consuming.

\section{Conclusion}

Educational research instruments are a mechanism that can measure intended matters. In relation to that, analyses from findings can explain the information on the item content. This means that the item status is able 
to elaborate and clarify the item statements. Because of that, the transformation of instrument development is more ergonomic, systematic, and empirical.

The transformation of instrument development involves an algorithm based on the correct principles and steps. All constructs and variables are planned based on the syllabus that supports the title of the proposed research. The IDS framework was developed by taking constructs, variables, and questioning methods into account to elaborate items with rubrics. All these elements were guided and supported by relevant literatures. Besides that, the validation and reliability determining processes were defined after the pilot test was conducted. The strengths of the output from the item development process where every construct or variable or item shown by the mean score can be elaborated qualitatively in the rubric form.

\section{References}

Anita, I., \& Jamil, A. (2012). How to measure students' creativity? Proceedings of The Asian Conference on the Social Sciences, Osaka, Japan.

Atan, L. (1978). Psikologi pendidikan (Educational psychology). Kuala Lumpur: DBP.

Husaini, M. H., \& Khairul, A. (2008). Kemahiran keusahawanan: Satu kajian analisis kandungan buku-buku teks (Entreprenuerial skills: A study on content analysis of textbooks). Proceedings of The Soft Skills and Social Well-Being Seminar, Kuala Lumpur.

Hussein, S. (2006). Keberkesanan Penggunaan Perisian Multimedia Dalam Pengajaran Dan Pembelajaran Lokus Dalam Dua Matra Terhadap Pelajar Tingkatan Dua. Fakulti Sains: Open University Malaysia.

Kamarul, A. J., \& Ab. Halim, T. (2007). Pendidikan Islam: Kaedah P \& P. Cet. Ke-2 (Islamic education: Teaching and learning methods Cet. Ke-2.). Skudai: Penerbit Universiti Teknologi Malaysia.

Ministry of Education. (2000). Surat pekeliling ikhtisas Bil. 1/2000: Penggunaan buku kerja (Circular letter No. 1/2000: Textbook). Kuala Lumpur: Ministry of Education.

Nunnally, J. C. (1982). Psychometric theory. New York, N.Y.: McGraw-Hill Inc..

Parson, T. (1978). Action theory and Uman condition. New York, N.Y.: Free Press.

Sahandri, M. G. H., Ramlee, I., Alias, M. T., \& Rose, E. M. H. (2013). The effectiveness of human capital in MARA Poly-Tech College (Ministry of Higher Education) (Unpublished research report, Universiti Pendidikan Sultan Idris).

Samsuddin, M. (2013). The study on remedial program evaluation in primary school (Unpublished Ph.D. dissertation, National University of Malaysia).

Siti Fatimah, A., \& Ab. Halim, T. (2010). Persepsi guru terhadap penggunaan bahan bantu mengajar berasaskan teknologi multimedia dalam pengajaran j-Qaf (Teachers' perception on the use of teaching aids based on multimedia technology in the teaching of j-Qaf). Journal of Islamic and Arabic Education, 2(2), 53-64.

Vijaya, K. K., \& Nair, K. (1996). Multimedia dalam pengajaran dan pembelajaran sains: Satu cabaran (Multimedia in the teaching and learning of science: A challenge). Proceeding of The National Science Curriculum Seminar, Langkawi.

Zainudin, H., Tengku, S. T. L., Mohad, N. A. G., \& Hamdan, S. (2007). Tahap penggunaan alat bantu mengajar di kalangan guru pelatih (The use of teaching aids among teacher trainers). Paper presented at The Educational Research Seminar, Teacher Training Institute, Batu Lintang. 